\title{
Onomastics and Creativity in Doña Bárbara y Pedro Páramo*
}

\section{ALFONSO GONZÁLEZ}

P OLITICAL BOSSISM, known south of the border as caciquismo, has been subjected to constant literary scrutiny in Latin America for decades. Two of the best known, because the most trenchant, analyses of this phenomenon are Romulo Gallego's Doña Bárbara (1929) and Juan Rulfo's Pedro Páramo (1955). Each was received enthusiastically and has gone through so many editions that to use the word "classic" in referring to them is not inappropriate in either case. Gallegos equates the cacique or "boss" with ignorance and illiteracy whereas Rulfo suggests that, however ugly and unpleasant, he is, has been, and will be the only hope of life in rural Spanish America. Among the techniques employed by these writers to project their own distinct worldview is the use of names.

Names in Doña Bárbara are generally invented and uncomplicated, their symbolism often being on a one-to-one basis; in contrast, names in Pedro Páramo are drawn from Biblical, mythological and regional sources and their allegorical meaning is more suggested than stated. The relationship of these names to their sources and to their allegorical meaning holds the key to a fuller understanding of the novel. Although the symbolism of most names in Doña Bárbara and that of the name Pedro Páramo have been studied, a comparative analysis of the process of naming and its effect, to the best of our knowledge, has not been done. ${ }^{1}$ We shall attempt

* Paper read at the Eleventh Annual Names Institute, Madison, N.J., May 6, 1972.

1 Among the sources for name symbolism in Doña Bárbara we find the following: Enrique Anderson Imbert, Spanish American Literature: A History (Detroit: Wayne State Univ. Press, 1969), II, 519 ff.; Arturo Torres Rioseco, The Epic of Latin American Literature (Berkeley and Los Angeles: Univ. of California Press, 1961), p. $183 \mathrm{ff}$; Fernando Alegría, Breve Historia de la Novela Hispanoamericana (México: De Andrea, 1966), p. 179 ff.; and Jean Franco, An Introduction to Spanish American Literature (London: Cambridge Univ. Press, 1969), p. $211 \mathrm{ff}$.

The implications of the etymology of the name Pedro in Pedro Páramo were first discussed by Octavio Paz, Corriente Alterna (México: Siglo XXI, 1967), p. 18.

Concerning the symbolic value of the name Paramo, Robert Mead, Jr. in a letter to The New York Times Book Review, August 9, 1959, p. 17, stated, "Selden Rodman's perceptive review of Juan Rulfo's Pedro Páramo, [June 7, 1959; p. 5] in which he quite properly emphasizes the symbolism of the novel, would have been even more meaningful if he had pointed out that 'Páramo' means desert or barren land in Spanish. For, despite the struggles of Rulfo's characters, their lives are unresolved and they exist, dead or alive, in a barren world of wasted effort." The symbolism to which Professor Mead refers has nothing to do with onomastics. 
to show how onomastic symbolism functions in each novel to create a worldview totally distinct from that of the other.

In Doña Bárbara the essential attributes of almost all characters or places are usually synthesized in their names. The name Bárbara, aside from being a valid proper name, is a feminine singular adjective which labels Latin American barbarism in the person of the protagonist, a woman cacique. She is superstitious, cruel, passionate, and practices witchcraft. In a word, Bárbara is a barbarian. She is also known as La Dañera, literally, "she-who-harms." The name Doña Bárbara is composed of two parts : doña from L. domina $(m)$ and Bárbara. ${ }^{2}$ The implication is that barbarism dominates, is master of the plains. We say master, not mistress, in this case because it is well known that Gallegos intended his doña Bárbara to represent the Venezuelan dictator Gómez. Hence doña Bárbara clearly means "Barbarism, the master of the llanos," which, like the prairies of our own Midwest, are synecdochic of the country as a whole.

Her antagonist, Santos Luzardo, or Holy Light, is the personification of law and order. He represents civilization, enemy of barbarism by definition. When civilization arrives, the cacique must either destroy it or disappear: darkness and ignorance disappear upon the arrival of light and knowledge; the two cannot coexist.

It is significant that Gallegos chooses the learned form Santos instead of the popular Sancho, both of which proceed from L. sanctus, "holy." 3 The implication is clear: Santos Luzardo is a man of learning, refinement and cosmopolitan background. A further consideration is the fact that for 300 years the name Sancho has projected an image of Don Quixote's peasant squire - short, fat, clumsy, comic - precisely the image Gallegos would wish to avoid here.

The surname Luzardo is ambiguous. The Luz from L. lux, lucis is easy enough; but the suffix -ardo can proceed from arder, "to burn," a verb which appears in the first person singular. (The meaning of the full name would then be, "I am the holy burning light of knowledge and civilization.") Or the -ardo may come from the MHG suffix -hart, "bold, hearty," in composition meaning "one who is too _-, as in drunkard ("one who is too drunk") or braggart ("one who brags too much"). In either case it is a common form in Spanish and the meaning would be "great or large light." If one accepts the suffix -ardo as a double

${ }^{2}$ L. dominam $>d u e \tilde{a} a$ except in proclisis as above, where $o$ does not diphthongize to ue because it is in a weak position.

${ }^{3}$ In reality, santos proceeds from the Latin nominative whereas, correctly speaking, Sancho proceeds from the accusative, on which case the Spanish vernacular was based. The occurrence of the nominative frequently indicates a learned influence such as that of the Church or the law courts. It is unlikely Gallegos was thinking of this but it does serve to underscore the implications of the name. 
entendre, the meaning would then be, "I am the great holy burning light, knowledge and civilization combined."

Mister Danger - this is his Spanish name in the novel - is a strong, cunning and opportunistic North American who symbolizes the threat as well as the actuality of North American barbarism. Marisela, the young daughter of Doña Bárbara, symbolizes the fertile and virgin Venezuelan plains. Abandoned by her mother, she is desired by the ruthless Yankee, Mr. Danger, but rescued at the end by the Holy Civilizer, Santos Luzardo. Marisela is possibly a combination of the name Maris Stella or "Sea Star," a well-known epithet of the Blessed Virgin. ${ }^{4}$

In Pedro Páramo the careful reader will note a different type of name symbolism. The difference is that the symbolism is not so obvious as in Doña Bárbara, a fact owing to its Biblical, mythological and regional roots. Pedro is from L. petru-, meaning "stone, foundation"; and Páramo from L. paramus, means "a cold, desolate, barren windswept plain." The implication of this name is that caciquismo is at the very root of Spanish American rural life. It is its foundation. Without it there is no life at all. As Pedro Páramo abuses his workers, he thrives and so does the town; when the cacique crosses his arms and stops his abuses, the town dies. Life in Comala begins and ends with him. Thus in the allegory of his name we perceive a foundation which is desolate and barren. This cacique has dozens of illegitimate children but is incapable of transcending himself in any one of them. That is, he fails to keep his town, Comala, alive for an extended period of time. He takes his children to be baptized as he would drive his cattle to be branded, and then proceeds to ignore them.

Eduviges Dyada is the old lady who meets Juan Preciado, the only legitimate child of the cacique, when the former arrives in the semideserted town of Comala. Eduviges means "He (or She) who fights in battles, faces the enemy." 5 Dyada comes from the word dyad "consisting of two." In the novel, Eduviges is the only character who violently protests her abject life. She escapes from Comala and from her wretched existence by committing suicide. Eduviges Dyada has a sort of psychic insight by means of which she can communicate with the dead. She exists on two levels: life and death, hence, a dyad.

In this novel there is also suggested mythical name symbolism even when the character is not named. As Juan Preciado stumbles from person to person in the gloomy ghost-like atmosphere of Comala, he encounters a brother and sister cohabiting. Donis is the name of the brother but that

\footnotetext{
4 This derivation is suggested by Webster's New International Dictionary, 2nd. ed. It appears the most reasonable available to us.

${ }^{5}$ Gutierre Tibón, Diccionario Etimológico Comparado de Nombres Propios de Persona, (México: UTEHA, 1956), p. 155.
} 
of the sister is never given. However, in this episode - and only here the narrator mentions repeatedly the name Estrella de la tarde, "Afternoon Star," in reference to Venus. This brings to mind the mythical love, though not incestuous, between Venus and Adonis. Donis' sister, like Venus, consistently appears naked. Also like Venus, she is the quintessence of sexual pleasure. She crawls in bed with the dying Juan Preciado trying to seduce him. Again when the bishop threatens her with eternal damnation if she does not cease her incestuous life, she simply ignores him.

We find symbolism related to Venus in the name of the cacique's hacienda, Media Luna, "Half Moon." The bleak light of a cold and barren moon, so necessary at night in the rural areas, is a fitting parallel to the indispensable nature of the cacique. Venus, who first is suggested by Donis' sister, later becomes almost a symbol for Susana San Juan, Pedro Páramo's only love and also his only unfulfilled wish. The only possible concurrence of the moon and the planet Venus - Pedro Páramo and Susana San Juan - is momentary and an optical illusion. Pedro Páramo expresses his longing for Susana: "Hundreds of meters away, higher than all the clouds, farther, farther away than anything else, you are hidden, Susana. Hidden in the immensity of God, behind his Divine Providence, where I cannot see you nor reach you, where my words cannot be heard." 6 Thus, Pedro Páramo and Susana San Juan can never be truly together.

Name symbolism and light symbolism are closely associated in both novels. In Doña Bárbara the cacique, symbol of the forces of evil, acts at night (her thefts and incantations take place under cover of darkness). When the Holy Light (Santos Luzardo) arrives, the darkness of barbarism and caciquism disappears. The cacique's very ranch is named $E l M i e d o$, literally "fear." The name of her place of residence stands for her instrument of government: fear. Santos Luzardo's ranch is named Altamira or "High Sights" since its goal is that of civilizing the plains. In Pedro Páramo the light (life) given off by the half moon is pale and weak but indispensable to the survival of Comala. Whereas the caciquismo embodied in the name Bárbara is completely bad and dark, that represented by the name Pedro Páramo manages to give off enough light to keep things going.

The bleak light emitted by a half moon could be compared to the light given off by lighted charcoal. The name of the town, Comala, suggests this. Comala is a feminization of the word comal, meaning the clay or round metal plate that rural Mexicans set on top of lighted charcoal to cook. The descent into Comala is in many ways like a descent into Hell. Abundio, one of the many illegitimate sons of the cacique, says of Comala: "That place is on top of the earth's lighted charcoals, in the exact entrance

6 Juan Rulfo, Pedro Páramo, 5th ed., (México: Fondo de Cultura Económica, 1964), p. 17. The translation is ours. All references to Pedro Páramo are from this edition. 
to hell." (p. 9). Thus Comala's atmospheric conditions and climate are embodied in the root of its name.

The name of Pedro Páramo's foreman is also symbolic. Fulgor Sedano, "Silky Brilliance," is incapable of giving off light by himself; he can only reflect a pale portion of it which he receives from Pedro Páramo. From the foregoing evidence, it is apparent even to the most casual observer that in this world of semi-darkness the most brilliant body seems to be Venus. Therefore, the only meaningful mechanism of escape is through love.

Susana San Juan is not only a symbol of Venus but also of the Biblical Susanna. Pedro Páramo, despite his good looks, audacity and power, is never able to inspire her love. Toward her the cacique manifests his only tenderness. Susana's father, a mining prospector, takes her from Comala. While away, she marries and is shortly widowed. Like most of the other characters, she makes little or no distinction between life and death and keeps dreaming of, and being faithful to, her deceased husband. According to the Biblical legend, Susanna was a chaste, beautiful wife. ${ }^{7}$ Two of the town elders desired her and spied on her as she was about to enter her bath. When they expressed their lascivious intentions, she rejected them. She was accused of infidelity by the elders and God sent an angel, Daniel, to testify in her behalf. This legend is often represented graphically by a sheep flanked by two wolves. In Pedro Páramo the sheep corresponds to Susana and the wolves to Pedro Himself and to Father Rentería. Pedro desires the beauty of her body, while Rentería covets her soul. Susana San Juan, as the Biblical Susanna, rejects successfully the two most prominent men in Comala.

Father Rentería's name is also symbolic. The noun renteria refers to a place in which activities related to rent and leasing occur. The cyclical alms collection, diezmos, primicias and other contributions, voluntary or otherwise, to the Church could be thought of as rent collection. The irony of the name Renteria lies in the fact that the parishioners are so poor that he must rely on the cacique for his support. On several occasions he refuses to allow entrance into heaven to deceased persons because their relatives cannot afford to pay for Gregorian masses or special services. Ironically, when Miguel Páramo, one of the countless children of the cacique and a sinner of regional repute, dies, the poor priest, who after all has to eat too, has no choice but to accept Pedro Páramo's money and ask God to intervene for the deceased, regardless of Miguel's moral debts.

Gallegos and Rulfo create two different ambients through the use of names and nicknames of minor characters. The names of secondary cha-

' Robert Henry Charles, The Apocrypha and Pseudepigrapha of the Old Testament (Oxford: Clarendon Press, 1913), pp. 638-651. 
racters in Doña Bárbara (Antonio, Lorenzo, Marisela, Pajarote) are universal. That is, they can be heard in an urban as well as in a rural area. In Pedro Páramo the names and nicknames of secondary characters are almost exclusively of a rural environment. In the city we usually do not hear names like Galileo, Lubianes, Ubillado, Sóstenes, La Cuarraca, El Tilcuate. Rural areas in the Spanish speaking countries not only tend to keep archaic forms of language in connected discourse but also to preserve archaic names. In rural Spanish America if a child is born on the day of a saint of the opposite sex, the saint's name is modified accordingly. For instance if a girl is born on the day of San Damián, she is named Damiana, and a boy born on the day of the Virgin Mary, is often named Mario. Thus names like Damiana, Prudencio, Filomeno and Doroteo contribute to give the flavor of a rural atmosphere in Pedro Páramo. Upon encountering characters with such unusual names, the reader has the distinct feeling of being in a different world, a world which in many parts of Latin America has not kept pace with the twentieth century.

Another significant fact is that Pedro Páramo is devoid of nicknames which connote tenderness or love. We are surprised never to find the diminutive, which is extremely common in Latin America, or the short form of a name, which is equally common there. The absence of tenderness embodied in names like Perico for Pedro or Lola for Dolores, helps create a dry atmosphere in which love does not exist. In Doña Bárbara, however, we find a warmth in such diminutives and nicknames as Mujiquita and Juan Primito.

Doña Bárbara and Pedro Páramo are two names used to describe the embodiment of the same phenomenon: caciquismo. The name Bárbara is almost totally negative in its connotation. It implies barbarism, ignorance and darkness. Name usage in Doña Bárbara, however, presents an optimistic worldview. The ignorance and barbarism of the cacique and the Venezuelan plains as well as the opportunistic North American Giant will be driven out by education and progress, the handmaidens of civilization. The name Pedro Páramo is ambiguous. We usually associate building, construction, progress, strength and durability with Pedro. Páramo, however, connotes a cold and desolate place; the names in Pedro Páramo are pessimistic and degrading. There is no alternative: meaningful love is nonexistent here. The cacique, as Abundio puts it, is a "living hate." The optimism of Doña Bárbara is a continuation of nineteenth-century faith in progress, while Pedro Páramo communicates the spiritual anguish of the twentieth century.

Ohio University 